\title{
Predicting activity results of the specialized tour operator
}

\author{
Marina Drobotova ${ }^{1, *}$, Viktoriia Krasnomovets $^{1}$, Olga Radchenko $^{1}$, and Artur Romanov ${ }^{2}$ \\ ${ }^{1}$ Cherkasy Bohdan Khmelnytsky National University, Department of Tourism, Hotel and Restaurant Business, Cherkasy, Ukraine \\ ${ }^{2}$ International University of Economics and Humanities Academician Stepan Demianchuk, Department of Management, Rivne, \\ Ukraine
}

\begin{abstract}
Hospitality provides wide opportunities for entrepreneurship. Feasibility and forecasting of results have always been relevant for implementation of entrepreneurial ideas. Aim of the study is to clarify specifics of forecasting of specialized tour operators' activities. Forecasting methods in tourism, as a rule, are based on opinion polls and extrapolation techniques. Difficulties with forecasting of results are related to indefinite part of specialized tours in overall volume of tours. And for every specialized tour this part depends from character and number of factors, which define demand for tourist product. Result of the study is the proposed algorithm for finding of planned sales of specialized tours for ensuring of profitable activities. With the example of gastronomical tours, which have good perspectives in Ukraine, it is proved that planning of more than $25-30 \%$ of specialized tours in overall sales of tours is not feasible. Finding of this research can be applied to product development, as well as marketing and strategic planning.
\end{abstract}

\section{Introduction}

The sphere of hospitality offers wide opportunities for entrepreneurship, as tourism is an international phenomenon, with constant steady growth and with profound impact on many spheres of economic and social development. Feasibility and forecasting of results have always been relevant for implementation of entrepreneurial ideas.

Tourism consumption can essentially be divided into institutionalized and non-institutionalized tourism [1] or into group package tours and individual travel [2].

Tourism system consists of tourists, touristgenerating regions, transit routes, destination regions, and the tourism industry, which are all arranged into spatial and functional connections and operate within broader physical, cultural, social, economic, political, and technological environments [3-4].

One of the main actors of the tourist market is a tour operator, as a producer of tourist product. The choice of tourist products set for production and implementation will ensure commercial success in the market. However, diversity and heterogeneity of tourist products and their great flexibility makes the process of forecasting the results of economic activity difficult and not always reliable. We consider which factors and conditions need to be taken into account when forecasting the results of a future company, namely specialized tour operator, on the example of gastronomy tourism.

Tour operator is directly involved in the planning, development, promotion and realization of tourism product for commercial purposes. Thus, the realization of tourism activity in the broad sense of the activity is carried out by various enterprises as economic agents of tourism market [5]. Package tourism as a combination of

${ }^{*}$ Corresponding author: marinadrobotova@ukr.net pre-arranged services, offered for an inclusive price, containing at least transport and accommodation together with some additional travel service, has become an integral part of modern culture [6].

Specialized tour operators concentrate their activities on the established tourist product or market segment. They can be tour operators of:

- special purpose in certain directions-destinations (tour to England, Italy, France, Switzerland, Egypt, Turkey, Thailand, etc.);

- special accommodation facilities (hotels, bungalows, agricultural homesteads, etc.) or certain tourist centers (e.g. Mallorca, the Costa del Sol, Antalya, etc.);

- certain type of tourism (safari in Kenya, religious tours to Rome, Jerusalem, skiing, etc.);

- a specific social group (tours for young people, couples, businessmen, etc.);

- transport type (bus tours, cruises, tourist trains, cycling routes, etc.)

Economic results of tour enterprise activity are estimated by different authors on various indicators. We consider the following indicators to be expedient for tour operators:

1. Marginal Profit $=$ Gross price - net price.

2. Gross Profit $=$ Marginal profit - Permanent Expenses.

3. The profit level of the developed tourism product $=$ Gross profit / Marginal profit.

4. Profitability of tourism product $=$ Gross profit * 100 / Total cost.

5. Payback period for capital investment $=$ Amount of the endowed capital associated with state registration of the company, license redemption and the authorized capital formation / Net profit of a tour company for a year. 
6. The invested capital efficiency $=$ Net profit of a tour company per year / The amount of the invested capital associated with the state registration of the company, license redemption and the authorized capital formation.

When creating a company, in our case - a specialized tour operator, it is advisable to estimate, first of all, marginal profit, net profit and payback period for capital investment. Calculation of these indicators is based on determining a production program of the tour company, namely, estimation of the number of implemented tours. In determining the production program and the performance of a specialized tour operator, prediction complexity is associated with the fact that the implementation share of the specialized tours in the total volume is uncertain. It depends on the nature and number of factors for each specialized tour.

For development of internal tourism problems of feasibility of sales plans and forecasting of activity results are identical for organized internal tourism of any kind. And, respectively, for any specialized tour operator. Forecasting methods, as a rule, are based on opinion polls and extrapolation techniques.

We consider the problems of predicting the activity results of a specialized tour operator on an example of culinary / food / gastronomy tourism. Despite of similarity of these notions, different organizations prefer only one of them. For example, UNWTO uses "gastronomy tourism", while such influential US-based organization as World Food Travel Association - "food (and beverage) tourism". The largest network of culinary and hospitality schools in the world Le Gordon Bleu prefers "culinary tourism" etc. While culinary tourism focuses on food products, gastro-tourism extends beyond what we eat. It includes how we eat, where and when we eat, and the reason behind eating a particular food [7].

A product of both world history and contemporary mass culture, culinary tourism is a scholarly field of study that is emerging as an important part of the tourism industry. It refers to adventurous eating, eating out of curiosity, exploring other cultures through food and the development of food as a tourist destination and attraction. In culinary tourism, the primary motivation for travel is to experience a specific food [8].

Taleb Rifai, UNWTO Secretary-General, noted in the foreword to the Second Global Report on Gastronomy Tourism, that gastronomy tourism offers enormous potential in stimulating local, regional and national economies and enhancing sustainability and inclusion. It contributes positively to many levels of the tourism value chain, such as agriculture and local food manufacturing. Linking gastronomy and tourism also provides a platform for the promotion of cultures through their cuisine. This not only assists in destination branding, but also helps to promote sustainable tourism through preserving valuable cultural heritage, empowering and nurturing pride amongst communities, and enhancing intercultural understanding. Through a visit to a food festival, cooking class or farm-to-table dining experience, tourists garner a better sense of local values and traditions [9].
The year of 2017 has been proclaimed by the United Nations as the International Year of Sustainable Tourism for Development. Gastronomy plays a significant role in the motivations for travel and tourism, developing gastronomy experiences for tourism is an attractive development strategy, because it appeals to high yield tourism. In addition, integrating gastronomy experiences into sustainable tourism development in rural and outlying areas helps to ease poverty. Because of the important relationship between gastronomy and other policy areas (agriculture, food production, country branding and cultural and creative industry), it is very important to develop an integrated and holistic approach to policy development and implementation [9].

The 1st UNWTO World Forum on food tourism was organized in 2015 with the aim to enhance management quality of the public and private sector in the field of gastronomy tourism. Based on the Forum, UNWTO published the first set of conclusions: food tourism is a cross-cutting segment, incorporating various economic sectors.

Although the tourism sector makes a significant contribution to the GDP of countries and job creation, the sustainability of this growth should be taken into consideration. Sustainable food tourism should incorporate the three pillars of sustainability, defined by UNWTO: environmental (reducing emissions), sociocultural (the authenticity of a destination) and economic (equitable distribution). Promotion should be global, but the experience local. Food tourism is a form of cultural preservation and should be configured around the quality and authenticity of the product and territory. Food tourism is a catalyst for the local economy: it provides the opportunity for job creation and the development of local economies, which in turn positively affects other sectors. It is also a major contributor to overcoming seasonality [9].

The urgency of considering the market of gastronomy tourism services is stipulated by the fact that it has a rich resource potential in Ukraine. It promotes the socio-economic development of regions, the popularization of potential tourism resources among the population. T. Lutska [10], O. Beidyk [11], V. Arkhipova [12], A. Popov [13], I. Shkola [14] et al. are among the researches, considering the problem.

The purpose of this article is to elaborate methods for predicting activity results of a specialized tour operator.

\section{Results}

Practice of recent years shows, that tourist flows increase in those regions of Ukraine, where specialized interactive tourism products like festivals and folk festivals are formed, based on local traditions. Ukraine has a unique potential for development of gastronomy tourism as competitive tourism product in the international and domestic markets (Table 1).

Gastronomic tourism has several directions: a tour of the countryside, a restaurant tour, an educational tour, an ecological tour, an event tour, a combined tour. In addition, there are such food and beverage tours, which 
offer learning only one meal in different areas. Popular French and Bulgarian wine gastronomic tours are among them, offering walks through vineyards, grape harvest, wine tasting. The demand for food and beverage tours has been actively developing in recent years. Germans, Englishmen, Americans and Japanese are among the great enthusiasts of this kind of leisure and entertainment.

Table 1. Culinary Festivals of Ukraine as Objects of Gastronomic Tourism.

\begin{tabular}{|c|c|}
\hline Event Name & Place and Period of Holding \\
\hline Bread Festival & $\begin{array}{l}\text { Ostriv Obyrok village, } \\
\text { Chernihiv region, August }\end{array}$ \\
\hline Watermelon Festival & $\begin{array}{l}\text { Hola Prystan village, Kherson } \\
\text { region, August }\end{array}$ \\
\hline "Berlybash Banush" Festival & \begin{tabular}{|l|} 
Kostylivka village, \\
Transcarpathian region, May \\
\end{tabular} \\
\hline Pork Festival & $\begin{array}{l}\text { Myrhorod, Poltava region, } \\
\text { May }\end{array}$ \\
\hline Birch Juice Festival & $\begin{array}{l}\text { Banyliv-Pidhirny village, } \\
\text { Chernihiv region, May }\end{array}$ \\
\hline $\begin{array}{l}\text { Derun Festival (Potato } \\
\text { Pancakes Festival) }\end{array}$ & $\begin{array}{l}\text { Korosten, Zhytomyr region, } \\
\text { September }\end{array}$ \\
\hline "Honey Savior" Festival & $\begin{array}{l}\text { Kolomyia, Ivano-Frankivsk } \\
\text { region, August }\end{array}$ \\
\hline Street Food Festival & Kyiv, November \\
\hline $\begin{array}{l}\text { "Transcarpathian Beaujolais" } \\
\text { Young Wine and Honey } \\
\text { Festival }\end{array}$ & Uzhhorod, November \\
\hline $\begin{array}{l}\text { Poltava Galushka and Varenyk } \\
\text { Holiday (Poltava Dumpling } \\
\text { Holiday) }\end{array}$ & Poltava, late June \\
\hline Honey Festival & $\begin{array}{l}\text { Mukachevo, Transcarpathian } \\
\text { region, September }\end{array}$ \\
\hline Plum Lequarium Festival & $\begin{array}{l}\text { Hecha village, Berehove } \\
\text { district, Transcarpathian } \\
\text { region, August }\end{array}$ \\
\hline Beer Festival & Lviv, Kyiv, October \\
\hline “KoropFest" Carp Festival & $\begin{array}{l}\text { Koropets, Monastyryska } \\
\text { district, Ternopil region, } \\
\text { August }\end{array}$ \\
\hline $\begin{array}{l}\text { "Lviv on a Plate" Gastronomic } \\
\text { Festival }\end{array}$ & Lviv \\
\hline $\begin{array}{l}\text { "For Coffee to Lviv" Coffee } \\
\text { Festival }\end{array}$ & Lviv \\
\hline Chocolate Holiday & Lviv, February \\
\hline "Hutsul Bryndza" Festival-Fair & $\begin{array}{l}\text { Rakhiv, Transcarpathian } \\
\text { region, September }\end{array}$ \\
\hline
\end{tabular}

One should stress that gastronomy tourism is a combination of ecology, culture and production. Pioneers in generating the idea of gastronomy tours are Italians, who skillfully combined the establishment of trade and technology industries with the involvement of tourists under the sign of tasty and healthy food.

Since, as noted above, absolutely all countries have conditions for the development of gastronomy tourism, this type of tourism can be considered among other priority directions of tourism sector development in Ukraine. As it was pointed out, one of the types of gastronomy tourism is restaurant tour.

Along with gastronomy achievements in Ukraine, there are paradoxical ones involving the lowest taxes on incomes of individuals-entrepreneurs in Europe, the cheapest internet connection; the high level of banking service.

Ukraine can be ranked the $4^{\text {th }}$ among 27 European countries after France, Italy and Spain by the quantity and quality of expensive (upper and middle class) restaurants, and the $1^{\text {st }}$ in terms of price / quality ratio. In Ukraine, practically all fuel stations have expensive coffee machines; it is difficult to find low-quality coffee in Ukraine. At the same time, for comparison, there is 1 restaurant for 600-700 inhabitants in the US, and 1 restaurant for 3500 inhabitants in Kyiv, and even less in other places. Restaurant service establishments are a symbol of hospitality in each city, a popular form of leisure and communication, and a sign of well-being of the population.

Poltava region in Ukraine was chosen to simulate the activity of the tour operator, specializing in gastronomy tourism. The economy of Poltava region is mainly formed by food industry and processing of agricultural products. It involves 133 enterprises and is represented by meat, dairy, sugar, baking, confectionery, fruit and vegetable, alcohol, brewing, oil and fat industries, and production of soft drinks. According to the volumes of food industry production, the region occupied the $8^{\text {th }}-9^{\text {th }}$ place in Ukraine in 2016, and in terms of output per capita, the region's indicators are higher than the average across the country [15].

Every year Poltava region shows its hospitality with "Gastronomy Events of Poltava Region" Interregional Tourist Festival taking place on the occasion of Europe Day celebration in the Poltava Corpus Park on May, 19. Tourism Department of the Regional State Administration offers a number of routes "TO THE FAIR IN SOROCHYNTSI!" [16]. Among 25 regions of Ukraine, Poltava region occupies the $16^{\text {th }}$ place in terms of tourist tax revenues to local budgets [17].

46 tourist companies operating in the regional centre are represented at stejka.com tourist portal. These companies have a similar set of services: bus tours to Ukraine and Europe; exotic and beach holidays around the world; skiing tours; weekend tours; ticket sales; insurance. The overwhelming majority of companies are travel agencies that offer travel abroad. "Kruhozir" enterprise is among the few tour operators offering recreational and educational tours to Ukraine, but there is no food tour among them [18]. Poltava region is in the middle group among 24 regions of Ukraine in terms of the provision of the population with the objects of restaurant industry. However, the available infrastructure shows the decline of economic life in the rural districts of the region. The development of agricultural (or socalled "green") tourism may be considered as certain reserve or niche for tourism industry. Therefore, the development of food tourism by creating specialized tour operator is a perspective economic direction for the region.

The assortment of gastronomy tour offer of the specialized tour operator under the conventional name "Travel-Shop" may be quite extensive; we consider an example of such a tour with the conventional name "Poltava Dainty". Bus will be used for transportation. 
The tour can be tailored for various categories of tourists. The main purpose of the trip is cultural and cognitive. The tour provides both basic and additional services. The route is circular according to the scheme. The total driving time spent by tourists on a one way trip is 9 hours 30 minutes, the total length of the route is 546 $\mathrm{km}$. This tour is designed for a group of tourists of 20 individuals and a group leader. Organizational and technical measures relate to: accommodation and meals (agricultural homesteads in Stasi and Dovhalivka villages); entertainment of tourists (participation in evening parties and master classes for the preparation of Ukrainian dishes); excursions in Gadiach town and Hoholeve village; preparation of relevant documentation. The company's Mercedes-Benz minibus is used for the transportation of tourists on the route. The limited cost of the tour (net price) is determined by a group of 20 tourists (Table 2).

Table 2. Limited Cost of "Poltava Dainty" Tour.

\begin{tabular}{|l|c|c|}
\hline \multicolumn{1}{|c|}{ Cost Item } & $\begin{array}{c}\text { Costs for 20 } \\
\text { persons, UAH }\end{array}$ & $\begin{array}{c}\text { Costs for 1 } \\
\text { person, UAH }\end{array}$ \\
\hline Minibus (round trip) & 6065 & 304 \\
\hline $\begin{array}{l}\text { Farmstead of green tourism, } \\
\text { 2 nights }\end{array}$ & 6000 & 300 \\
\hline $\begin{array}{l}\text { Meals in farmsteads of } \\
\text { green tourism }\end{array}$ & 7000 & 350 \\
\hline Insurance & 1800 & 90 \\
\hline 4 excursions & 1600 & 80 \\
\hline $\begin{array}{l}\text { Master class for cooking } \\
\text { Ukrainian dishes }\end{array}$ & 600 & 30 \\
\hline $\begin{array}{l}\text { Organizing and conducting } \\
\text { of evening parties }\end{array}$ & 2000 & 100 \\
\hline Total & 25065 & 1253 \\
\hline
\end{tabular}

There are 6 employees in the "Travel-Shop" tourism enterprise: a director, an accountant, an international tourism manager, an internal tourism manager, and two drivers. The enterprise remuneration fund is: basic salary; additional salary (individual prizes for personal merits, monthly personal allowances, quarterly bonuses, annual bonuses); incentive and compensating payments (material assistance; incentives; social guarantee and compensation package).

The production costs of the tour (net price + current expenses for the development and sale of the product (salary of the staff, depreciation of equipment, maintenance of premises, advertising costs, marketing, travel, etc.) is $27065 \mathrm{UAH}(25065 \mathrm{UAH}+1500 \mathrm{UAH}$ service cost for a group leader +500 UAH current expenses for the development and sale of the product), respectively per 1 tourist $=27065 / 20=1353 \mathrm{UAH}$.

The price of the tour offer on the market (gross price) $=$ production cost of the tour + profit of a tour operator + commission reward of a travel agent (Table 3).

The tour price for implementation by a tour operator is $1760 \mathrm{UAH}$.

The tour price for implementation by a travel agent is 1936 UAH.

The main product range of the "Travel-Shop" tourist enterprise is:
- organization of gastronomy and festival tours in Ukraine;

- summer and winter holidays abroad (Egypt, Cyprus, Turkey, Maldives, Italy, Seychelles, Thailand, Dominican Republic, Mexico, USA, Montenegro, Croatia, Spain, United Kingdom, Cuba, Mauritius, OAU, etc.);

- bus tours in Europe.

Table 3. Price Structure of the Tour Offer.

\begin{tabular}{|c|c|c|}
\hline $\begin{array}{c}\text { Production Cost } \\
\text { of the Tour }\end{array}$ & $\begin{array}{c}\text { Tour Operator's } \\
\text { Profit (30\%) }\end{array}$ & $\begin{array}{c}\text { Commission Fee of the } \\
\text { Travel Agent (10\%) }\end{array}$ \\
\hline 1353 & 406 & 176 \\
\hline \multicolumn{2}{|c|}{1760} \\
\hline \multicolumn{3}{|c|}{1936} \\
\hline
\end{tabular}

The forecast of incomes and expenses of the "TravelShop" tour operator is based on the sale volume of the developed tour. In forecasting, the information based on the study results of the tourist service market is used, and the method of forecasting as well as expert estimations are applied.

We, as experts, believe that the demand for the developed tour will be in the amount of 5 group tours per month, the tour is possible from May to October inclusively taking into account the seasonal character of it. The most realistic ratio of specialized and other tours implementation is 50:50. The income from the tourist activity of the "Travel-Shop" tour operator is presented as the sum of gross proceeds from the sale of services (without VAT). The proceeds were calculated based on the arrival plan of the groups. Since the price of one tour for the implementation of a tour operator is $1760 \mathrm{UAH}$, the gross income of the company at $100 \%$ sales of the estimated volume of the developed tours for a year period can be calculated as follows: $1760 \times 20 \times 30=$ 1056 thousand UAH (proceeds from the implementation of the specialized tours per year). Algorithm for defining of the planned part of specialized tours for ensuring profitable activities is based on marginal analysis. Planning of marginal profit of the "Travel-Shop" company according to an optimistic, pessimistic and realistic forecast for the performance is shown in Tables $4-6$.

The data in Table 4 illustrate the forecast of economic performance of the enterprise, provided that the proceeds from the sale of specialized tours is $25 \%$ in the total amount of revenues. Under such conditions, the gross income of the "Travel-Shop" company is 680.099 thousand UAH, and income profitability is $16.1 \%$. This forecast is optimistic according to the results of the activity, but does not reflect the essence of the sale specialization of tourism enterprises.

The data in Table 5 show a realistic forecast of the economic performance of an enterprise, provided that the proceeds from the sale of the specialized tours is $50 \%$ of the total revenues, which is more acceptable to the realities of the tourism market and the conditions of the enterprise specialization. Under such conditions, the loss of the "Travel-Shop" company is about $(-1.401)$ thousand $\mathrm{UAH}$, and the profitability is $(-0.07) \%$. This forecast is considered realistic for the results of the 
enterprise activity and the sale share of the specialized tours.

Table 4. Planning Marginal Profit for the "Travel-Shop" Enterprise for the Forecast Year (Optimistic Forecast).

\begin{tabular}{|c|c|c|}
\hline Indicator & $\begin{array}{l}\text { Calculation } \\
\text { Algorithm }\end{array}$ & $\begin{array}{l}\text { Value, } \\
\text { UAH }\end{array}$ \\
\hline $\begin{array}{l}\text { 1. Revenues from operating } \\
\text { activities }\end{array}$ & $\operatorname{art} .1 .1+\operatorname{art} .1 .2$ & 4224000 \\
\hline $\begin{array}{l}\text { 1.1. Income (revenue) from the } \\
\text { sale of specialized tours }(25 \%)\end{array}$ & & 1056000 \\
\hline $\begin{array}{l}\text { 1.2. Income from selling of other } \\
\text { tours }(75 \%)\end{array}$ & & 3168000 \\
\hline 2. Variable costs & & 2956800 \\
\hline 3. Marginal profit & art. $1-$ art. 2 & 1267200 \\
\hline 4. Fixed costs & & 587101 \\
\hline 5. Gross profit (loss) & art. $3-\operatorname{art.} 4$ & 680099 \\
\hline 6. Profitability of revenues, $\%$ & $\begin{array}{l}\text { art. } 5 \times 100 / \\
\text { art. } 1\end{array}$ & $16.10 \%$ \\
\hline
\end{tabular}

* If other tours are implemented, the income is considered by the ratio 25:75.

Table 5. Planning Marginal Profit for the "Travel-Shop" Enterprise for the Forecast Year (Realistic Forecast). ${ }^{*}$

\begin{tabular}{|l|c|c|}
\hline \multicolumn{1}{|c|}{ Indicator } & $\begin{array}{c}\text { Calculation } \\
\text { Algorithm }\end{array}$ & $\begin{array}{c}\text { Value, } \\
\text { UAH }\end{array}$ \\
\hline 1. Revenues of operating activities & art.1.1 + art.1.2 & 2112000 \\
\hline $\begin{array}{l}\text { 1.1. Income (revenue) from the } \\
\text { sale of a specialized tour (50\%) }\end{array}$ & & 1056000 \\
\hline $\begin{array}{l}\text { 1.2. Income from selling other } \\
\text { tours (50\%) }\end{array}$ & & 1056000 \\
\hline 2. Variable costs & art. 1 - art. 2 & 633600 \\
\hline 3. Marginal profit & & 635001 \\
\hline 4. Fixed costs & art. 3- art. 4 & -1401 \\
\hline 5. Gross profit (loss) & art. 5 x 100/ \\
art. 1 & $-0.07 \%$ \\
\hline 6. Profitability of revenues, $\%$ & * If other tours are implemented, the income is considered by
\end{tabular}
the ratio 50:50.

The data in Table 6 illustrate the most pessimistic forecast of the economic performance of the enterprise, provided that revenues from the sales of the specialized tours is $75 \%$ of the total revenue.

Table 6. Planning Marginal Profit for the "Travel-Shop" Enterprise for the Forecast Year (Pessimistic Forecast).*

\begin{tabular}{|l|c|c|}
\hline \multicolumn{1}{|c|}{ Indicator } & $\begin{array}{c}\text { Calculation } \\
\text { algorithm }\end{array}$ & $\begin{array}{c}\text { Value, } \\
\text { UAH }\end{array}$ \\
\hline 1. Revenues of operating activities & art.1.1 + art.1.2 & 1408000 \\
\hline $\begin{array}{l}\text { 1.1. Income (revenue) from the } \\
\text { sale of a specialized tour (75\%) }\end{array}$ & & 1056000 \\
\hline $\begin{array}{l}\text { 1.2. Income from selling other } \\
\text { tours (25\%) }\end{array}$ & & 352000 \\
\hline 2. Variable costs & art. 1 - art. 2 & 422400 \\
\hline 3. Marginal income & & 635001 \\
\hline 4. Fixed costs & art. 3 - art. 4 & -212601 \\
\hline 5. Gross profit (loss) & $\begin{array}{c}\text { art. 5 x 100 / } \\
\text { art. 1 }\end{array}$ & $-15.10 \%$ \\
\hline 6. Profitability of revenues, $\%$ & \\
\hline
\end{tabular}

${ }^{*}$ If other tours are implemented, the income is considered by the ratio $75: 25$.
However, such a share is a clear factor showing the specialization of the tourist enterprise. Under such conditions, the "Travel-Shop" company has a loss of 212.601 thousand UAH, and profitability of incomes is $15.1 \%$.

The calculations, presented in tables $4-6$ make it possible to conclude that it is impossible to achieve positive economic results of a specialized tour operator through the sale of the developed gastronomy tour for domestic tourists. The forecast of economic results of an enterprise is positive only if the proceeds from the sale of the specialized tours make up $25 \%$ of the total revenues, although this contradicts the conditions of specialization. The forecast shows the realities of the tourist market of Ukraine; however, it is impossible to get profit, if internal tours are mostly implemented. But at the same time sales of outbound tours ensures profitable business. The issue of forecasting the necessary structure (ratio) of domestic and outbound tours remains open, as it is difficult to identify and anticipate all the factors, which form the demand for these tours.

The analysis of the offer by domestic tour operators (Table 7) allows stating that, first, gastronomy tourism has not a mass character in Ukraine.

Table 7. Offer of Gastronomy Tours by Domestic Tour Operators in Ukraine.

\begin{tabular}{|c|c|c|}
\hline $\begin{array}{c}\text { Tour } \\
\text { Enterprise } \\
\end{array}$ & Travel Route & $\begin{array}{c}\text { Tourism Product } \\
\text { Name }\end{array}$ \\
\hline $\begin{array}{l}\text { "Unique } \\
\text { Ukraine" } \\
\text { Tourism } \\
\text { Company }\end{array}$ & $\begin{array}{l}\text { Mukachevo - Silce - } \\
\text { Khmilnyk - Shalanky - } \\
\text { Botar-Uzhhorod - Kosyno } \\
\text { - Berehovo - Mukachevo }\end{array}$ & $\begin{array}{l}\text { "Transcarpathian } \\
\text { Beaujolais" }\end{array}$ \\
\hline $\begin{array}{l}\text { "Galicia-Tour" } \\
\text { Tour Operator }\end{array}$ & t & $\begin{array}{l}\text { "From 'Spazeir' to } \\
\text { the Cup" }\end{array}$ \\
\hline $\begin{array}{l}\text { "UA Country" } \\
\text { Tour Operator }\end{array}$ & $\begin{array}{l}\text { Volovets - Huklyvy - } \\
\text { Mizhhiria - V. Byihan - } \\
\text { Mukachevo - Huklyvy }\end{array}$ & $\begin{array}{l}\text { "Culinary } \\
\text { Transcarpathia" }\end{array}$ \\
\hline $\begin{array}{l}\text { "Vyd } \\
\text { Mandriv" } \\
\text { ("Journey } \\
\text { Type") Tour } \\
\text { operator }\end{array}$ & $\begin{array}{l}\text { Lviv -Chynadievo - } \\
\text { Mukachevo - Berehovo - } \\
\text { Uzhhorod - Lumshory - } \\
\text { Lviv }\end{array}$ & $\begin{array}{l}\text { "Transcarpathian } \\
\text { Dessert" } \\
\text { Gastronomic Tour }\end{array}$ \\
\hline $\begin{array}{l}\text { "Vidvidai" } \\
\text { ("Visit") Tour } \\
\text { operator }\end{array}$ & Kyiv & $\begin{array}{l}\text { “Aristocratic Tea } \\
\text { Party” }\end{array}$ \\
\hline
\end{tabular}

\section{Conclusions}

It is now much more important than ever before to consider the potential of gastronomy tourism as integral part of economic growth, social inclusion, cultural and environmental preservation, and mutual understanding. Result of the research is the proposed algorithm for definition of planned share of specialized tours in overall sales of tourist products for ensuring of profitable business. Share of internal specialized tours in total sales of a specialized tour operator should be not more than $25-30 \%$. The forecast calculations, offered above, confirm that sales of specialized tours only for local tourists are not feasible for ensuring positive economic 
results of a specialized tour operator. The issue of forecasting the optimal ratio between internal and international tourism remains open, as it is very difficult to define all factors, which can influence demand for such tours.

The proposed algorithm has an universal character for all specialized tour operators, results of calculations are also of universal nature for them. Results from this research can be applied to product development, as well as marketing and strategic planning.

\section{References}

1. Cohen, E.: Towards a sociology of international tourism. Social Research, 39(1), 164-182 (1972)

2. Wang, K.C., Hsieh, A.T., Huan, T.C.: Critical service features in group package tour: An exploratory research. Tourism Management, 21(2), 177-189 (2000)

3. Leiper, N.: The framework of tourism: Towards a definition of tourism, tourist, and the tourist industry. Annals of Tourism Research, 6(4), 390407 (1979)

4. Travis, A.S.: Tourism destination area development (from theory into practice). In: Moutinho, L. (ed.) Tourism Marketing and Management Handbook, pp. 487-498. Prentice Hall International, Hertfordshire (1989)

5. Brych, V.Y. (ed.): Turopereyting (Tour Operating). Econ. dumka, Ternopil (2017)

6. Raikkonen, J.: Enabling experiences - the role of tour operators and tour leaders in creating and managing package tourism experiences. Sarja/Series A-13:2014. Turku School of Economics. Suomen yliopistopaino Oy - Juvenes Print, Turku (2014)

7. Tan, D.: Culinary Tourism. Now Trending. https://www.cordonbleu.edu/news/culinarytourism/en (2019). Accessed 10 Mar 2019

8. Long, L.M. (ed): The Oxford Handbook of Food History. Oxford University Press, New York (2012)

9. Second Global Report on Gastronomy Tourism. Affiliate Members Report, vol. 16. World Tourism Organization, Madrid (2017)

10. Lutska, T.: Otsinka konkurentospromozhnosti biznes-protsesiv pidpriemstv-turoperatoriv (Competitiveness business processes estimation of tour-operators). Efektyvna ekonomika. 2. http://www.economy.nayka.com.ua/index.php?op=1 $\& z=473$ (2011). Accessed 10 Mar 2019

11. Beidyk, O.O.: Rekreatsiyno-turistichni resursi Ukrayini: metodologiya i metodika analizu, terminologiya, zonuvannya (Recreational and Tourism Resources of Ukraine: Methodology and Methods of Analysis, Terminology, Zoning). Kyiv University, Kyiv (2012).

12. Arkhipov, V.V.: Organizatsiya restorannogo gospodarstva (Organization of Restaurant
Economy). Centre for Educational Literature, Kyiv (2010).

13. Popov, A. A.: Analiz i rozrobka algoritmichnoyi modeli turoperatora (Analysis and development of an algorithmic model of a tour operator). Radio and Computer Systems. 1, 170-174 (2014)

14. Shkola, I. M. (ed.): Menedzhment industriyi turizmu (Management of Tourism Industry). Knygy - XXI, Chernivtsi (2015)

15. Ukraine Today. Poltava Region Leading Ukrainian Companies Database. http://www.rada.com.ua/ukr/RegionsPotential/Polta va (2019). Accessed 11 Mar 2019

16. Poltava Region: Map and information of Poltava region. http://poltava-obl.ru (2019). Accessed 20 Mar 2019

17. Information Relating the Indicators of Tourism and Health Resort Development. www.me.gov.ua/Documents/Download?id=2571969 9 (2018). Accessed 11 Mar 2019

18. "Kruhozir": Tourism Company. http://krugozor.com.ua (2019). Accessed 11 Mar 2019 